\title{
Marker regression mapping of QTL controlling flowering time and plant height in a spring barley (Hordeum vulgare L.) cross
}

\author{
JEREMY BEZANT†お, DAVID LAURIE* †, NICKY PRATCHETT†, JAN CHOJECKI§ \& \\ MIKE KEARSEY $\ddagger$ \\ $\dagger$ John Innes Centre, Colney Lane, Norwich NR4 7UH, $\ddagger$ School of Biological Sciences, University of Birmingham, \\ Birmingham B15 $2 \pi$ T and §Zeneca Seeds U.K. Ltd, Jealott's Hill Research Station, Bracknell, Berkshire RG12 6EY, \\ U.K.
}

\begin{abstract}
An RFLP map was constructed from 99 doubled haploid lines of a cross between two spring barley varieties (Blenheim $\times \mathrm{Kym}$ ) and used to map quantative trait loci (QTL) controlling ear emergence time and plant height using a marker-regression approach. Three QTL affecting plant height were identified. The largest effect was from the denso dwarfing gene, present in Blenheim, on chromosome $3(3 \mathrm{H}) \mathrm{L}$. Two other effects were found, one on $7(5 \mathrm{H}) \mathrm{L}$ and one on $1(7 \mathrm{H}) \mathrm{L}$. The denso gene also had a major effect on ear emergence time. However, eight additional QTL for ear emergence were also identified. Two of these were in regions previously identified as carrying the $S h$ and $S h 2$ vernalization response genes, suggesting that allelic variation at these genes may affect ear emergence time in spring barley crosses. Comparisons with maps of related species show conservation and collinearity of markers and genes.
\end{abstract}

Keywords: comparative mapping, flowering time, height, Hordeum vulgare, quantitative trait loci (QTL), RFLP-mapping.

\section{Introduction}

Ear emergence time (heading date) is an important factor in adapting cereal varieties to environments and in maximizing yield potential. The control of plant height can be used to reduce yield loss arising from lodging and to increase harvest index. In barley these traits are often found to be highly heritable and correlated, suggesting that they are controlled by relatively few genes which are easy to identify and map genetically, e.g. Barua et al. (1993) and Laurie et al. (1993). However, in many cases the traits vary quantitatively suggesting that they are controlled by many genes.

Molecular marker maps, usually based on RFLPs, have been widely used to map quantitative trait loci (QTL), for example in barley (Hayes et al., 1993a; Backes et al., 1995), maize (Edwards et al., 1992) and almond (Asins et al., 1994). Once the QTL locations are known, their effects on the character can be determined and the genes involved can be manipulated for breeding purposes.

Several statistical methods are available to detect and locate QTL. The most popular analytical

*Correspondence. method is that of flanking marker mapping, either by the log-likelihood approach of interval mapping, as implemented by MAPMAKER/QTL (Lander \& Botstein, 1989), or by multiple regression (Haley \& Knott, 1992; Martinez \& Curnow, 1992). Combining interval mapping with multiple regression has been proposed to attempt to separate the effects of possible multiple linked QTL (Jansen, 1992; Zeng, 1994). Cofactors are used to reduce the effect of background noise or variation by taking into account the variation of these selected markers with the QTL.

Kearsey \& Hyne (1994) presented a markerregression approach which can be used for populations derived from an $F_{1}$. It is as reliable as the interval mapping and multiple regression approaches, but has wider application and is capable of hypothesis testing. It also relies on simple statistical procedures, using standard statistical software. This method is used in this study to search for QTL.

Recently RFLPs have been used to locate several major genes controlling plant height and ear emergence time in barley and related species. The denso dwarfing gene, present in many spring barley varieties in Europe, has been mapped to the long arm of chromosome 3(3H) (Barua et al., 1993; Laurie et al., 
1993). Genes controlling photoperiod and vernalization response have been mapped in barley (Hackett et al., 1992; Pan et al., 1994; Laurie et al., 1995), wheat (Galiba et al., 1995; Worland, 1995) and rye (Plaschke et al., 1993).

This paper describes the detection and location of QTL controlling ear emergence time and plant height in a cross between two spring barley varieties and compares their locations to effects previously identified in other barley crosses and in other Triticeae species.

\section{Materials and methods}

\section{The mapping population}

A population of 99 doubled haploid (DH) lines was produced from $F_{1}$ plants of a cross between the spring barley varieties Blenheim and Kym using the Hordeum bulbosum method (Simpson \& Snape, 1981). Blenheim was recommended as a malting variety for English and Welsh farmers from 1987 to 1994 by the National Institute of Agricultural Botany (N.I.A.B., 1994); Kym was recommended by N.I.A.B. from 1981 to 1988.

\section{Field experiments}

The 99 lines were evaluated over three years in field plots sown at the John Innes Centre field station, Norfolk. Lines were replicated as five randomized blocks. In 1991 and 1992 each block contained $1 \mathrm{~m}$ rows of 11 plants of each $\mathrm{DH}$ line, and two rows of 11 plants of each parent, and in $1993,6 \mathrm{~m} \times 1.25 \mathrm{~m}$ plots were sown using a seed drill. Agronomic treatments were as for normal farm management of malting barley.

Flowering time was recorded when half the plants in the row or plot had half the ear emerged from the flag leaf on the leading tiller. The number of days after the first plot or row to flower was used to score each replicate. Final plant height was calculated from samples of five main tillers taken from each row or plot. Tillers were measured from ground level to the tip of the ear (excluding awns). Flowering time was recorded in 1991 and 1993. Final plant height was recorded in 1991, 1992 and 1993.

\section{RFLP analysis}

DNA was extracted from each DH line as described by Devos et al. (1992) or by a modified CTAB method (Murray \& Thompson, 1980). Polymorphisms were selected by hybridizing a selection of
cDNA and genomic clones with DNA of the parental lines digested with EcoRI, EcoRV, DraI or HindIII using the methods of Devos et al. (1992) except that probes were denatured by adding $1 / 10^{\text {th }}$ volume $3 \mathrm{~m} \mathrm{NaOH}$. Variation at the Hor2 (B hordein) and Horl (C hordein) storage protein loci was characterized by SDS-PAGE electrophoresis of mature grains (Payne et al., 1981). A $\beta$-amylase ( $\beta$-amy-H1) isozyme polymorphism was also characterized using the method of Sharp et al. (1988). $\mathrm{Per}-\mathrm{H} 2$ and $\mathrm{Per}-\mathrm{H} 4$ peroxidase polymorphisms were characterized as described by Liu et al. (1990). Linkage maps were constructed using JOINMAP v.1.4 (Stam, 1993) using the Haldane mapping function which was required for marker-regression.

RFLP probes were selected from a number of different published maps to give good coverage of the barley genome and to enable comparisons to be made with other maps. Probe prefixes are as follows: $X p s b$, from John Innes Centre barley genomic DNA library; Xpsr, from John Innes Centre wheat genomic or cDNA libraries; Xmwg, barley genomic DNA (Graner et al., 1991); Xwg, wheat genomic DNA (Heun et al., 1991); Xbcd, barley cDNA (Heun et al., 1991); Xcdo, oat cDNA (Heun et al., 1991); and Xzen, barley genomic DNA, Zeneca Seeds U.K. Ltd. Known function clones are as follows: $X p s r 2$ ( $\alpha$ Amy1) (Lazarus et al., 1985), $\alpha$-amylase cDNA; Xwye805 (Waxy), Waxy cDNA (Rohde et al., 1988); and Xrsq805b (Embpl) (Guiltinan et al., 1990), early methionine binding protein cDNA.

\section{Data analysis}

Primary statistical analyses were performed using the GENSTAT statistical package (Genstat 5 committee, 1987). Analysis of variance (ANOVA) was used to detect differences between years, blocks and DH lines for each trait. ANOVA was also used to detect associations between RFLP alleles and all scored traits by comparing the variation between the allele class means at each marker locus with variation between lines within classes.

The marker-regression approach (Kearsey \& Hyne, 1994) was then used to detect and map QTL using the line means. A linkage group of at least three markers is required for marker-regression analysis. Single or paired markers were analysed individually using ANOVA. Marker-regression (MR) surveys the linkage group at $2 \mathrm{cM}$ intervals and gives the most likely position of the QTL together with its additive effect. The difference between marker genotype means (the additive effect, $\delta_{i}$ ) at a locus is regressed against a function of the recombination 
frequency between that locus and a putative QTL. The expected value of the additive effect $\left(\delta_{i}\right)$ at a marker is:

$\delta_{i}=\left(1-2 R_{i}\right) \alpha$,

where $\alpha$ is the additive effect of the QTL and $R_{i}$ is the recombination frequency between the $i$ th marker and the QTL.

\section{Results}

\section{Linkage mapping}

A total of 99 polymorphisms were mapped including 93 RFLPs, two storage proteins and four isozymes.

Analysis using JoInMAP v.1.4 (Stam, 1993) gave 10 linkage groups (linkage group LOD threshold fixed at 3.0) (see Fig. 1). Using single-copy markers previously assigned to chromosome arms and by hybridization of additional probes to wheat/barley telosomic addition lines (Islam, 1983), each linkage group could be assigned to a chromosome or chromosome arm. Testing additional probes likely to map in the gaps in the linkage groups failed to identify segregating markers, suggesting that these chromosome regions had low levels of polymorphism. Segregation distortion was detected on chromosome $1(7 \mathrm{H}) \mathrm{S}$. Tabata (1961) reported linkage of a gametophytic factor, $G a$, to the waxy locus in barley causing segregation distortion. In this cross the waxy locus maps to the centre of the distorted region.

\section{Analysis of agronomic traits}

ANOVA detected significant differences between DH lines for each trait in all three years. Heritabilities (based on row $(1991,1992)$ or plot (1993) means) for ear emergence time were 0.74 (1991) and 0.87 (1993), and for plant height, heritabilities were 0.89 (1991), 0.69 (1992) and 0.76 (1993). Genotype by environment interaction contributed 3.5 per cent of the variation for both ear emergence time and height, so the traits were averaged over years for QTL mapping.

\section{QTL mapping}

ANOVA of allele class means for all markers and marker-regression (Kearsey \& Hyne, 1994) were used to detect and locate trait loci. The additive effects (half the difference between the allele class means) and levels of significance obtained from ANOVA for significant loci are shown in Fig. 1. QTL located by marker-regression are also shown with their additive effect and level of significance, and are highlighted by boxes. The residual mean square in the marker-regression (MR) analysis was used to test the adequacy of the simple one-QTL model on a given linkage group. An ' $\&$ ' character after the QTL name indicates the likely presence of one or more additional QTL in the same linkage group as the QTL detected by marker-regression. The sizes and locations of the additional QTL are not known.

\section{$Q T L$ for final plant height}

Over the three years of the experiment the average height of Blenheim was $78.23 \mathrm{~cm}$ and $\mathrm{Kym}$ was $77.91 \mathrm{~cm}$. Kym was expected to be taller than Blenheim from National List Trial data (N.I.A.B., 1994). However, this difference was not observed in the experiments. This may result partly from the use of single rows of spaced plants or from competition between genotypes. Blenheim is known to carry the denso dwarfing gene, whereas $\mathrm{Kym}$ is not known to. Therefore, height-reducing genes were expected to be found in Kym or height-increasing genes in Blenheim.

Prostrate juvenile growth (vs. indeterminate seedling growth) is characteristic of denso (data not shown). Both this character and plant height were used to classify the lines into allelic groups for the denso gene, which was then mapped as a morphological marker to the long arm of chromosome $3(3 \mathrm{H})$. The position was consistent with previous reports (Barua et al., 1993; Laurie et al., 1993). ANOVA detected an additive effect of $8.11 \mathrm{~cm}$ at this locus, which accounted for 67 per cent of the variation for height in this experiment. MR identified this as the most significant region for plant height with

Fig. 1 An RFLP map of the Blenheim $\times$ Kym cross. Distances are in cM (Haldane). Additive effects for ear emergence time $(\mathrm{E})$ (days) and plant height $(\mathrm{H})(\mathrm{cm})$ are given for those loci found to have a significant effect on the character by ANOVA. Values were calculated as Blenheim minus Kym. Levels of significance are: ${ }^{*} P \leq 0.05,{ }^{* *} P \leq 0.01,{ }^{* * *} P \leq 0.001$. QTL located by MR are shown in boxes with their additive effects and significances. A triangle by a locus name indicates that the marker or pair of markers was not linked to the main linkage group. Loci on $1(7 \mathrm{H}) \mathrm{S}$ marked with a square showed segregation distortion in favour of the Blenheim allele. Arm locations (short (S) or long (L)) are given where known for the marker nearest to the centromere. 


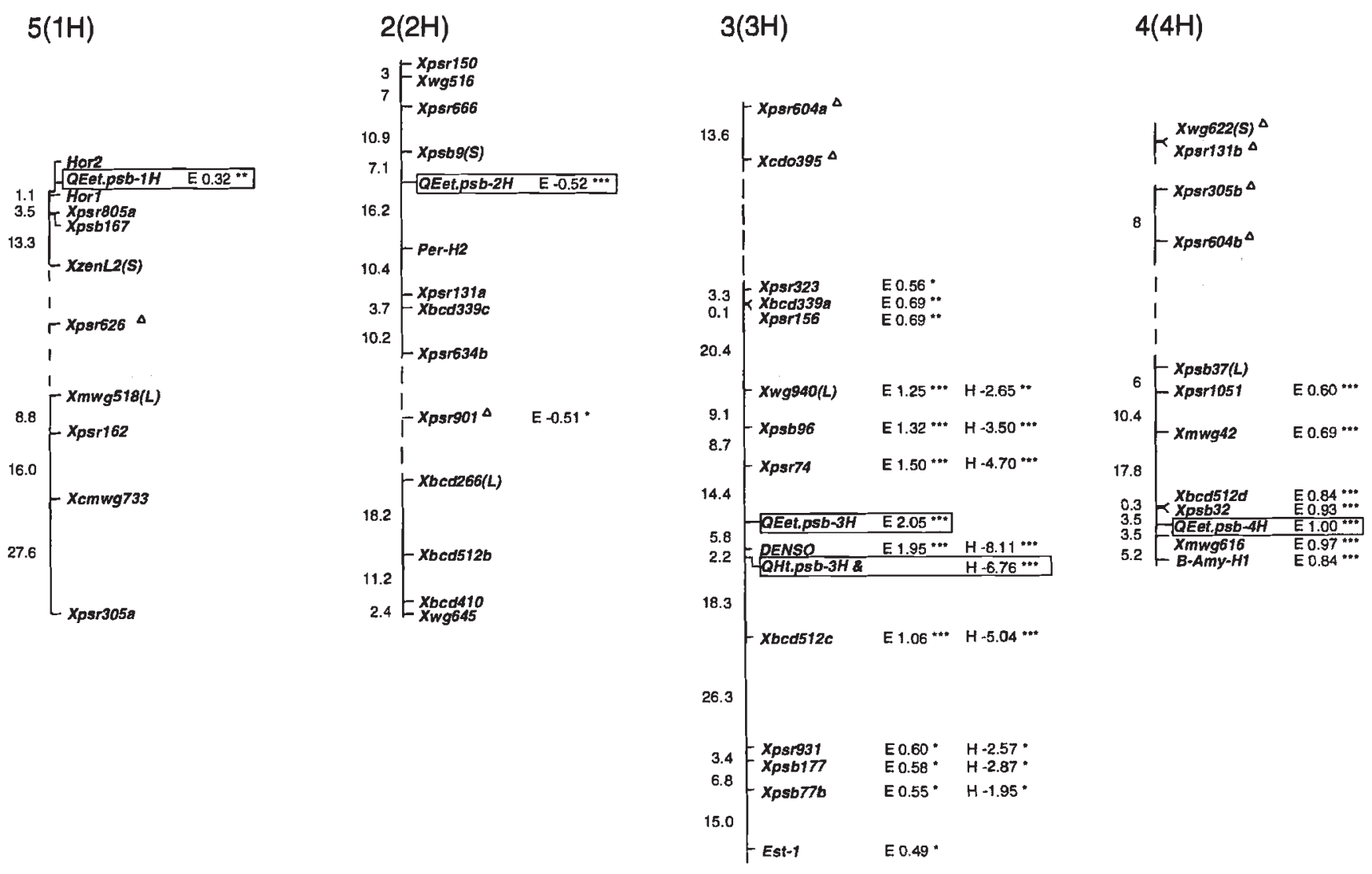

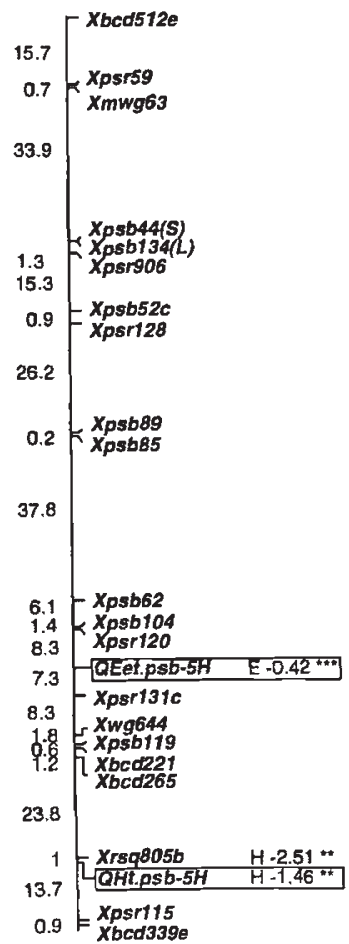

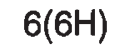

1(7H)

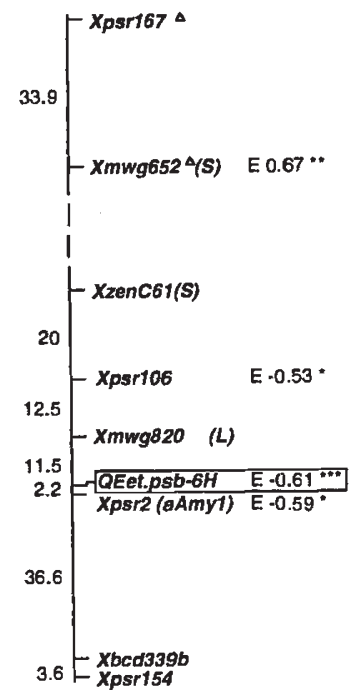

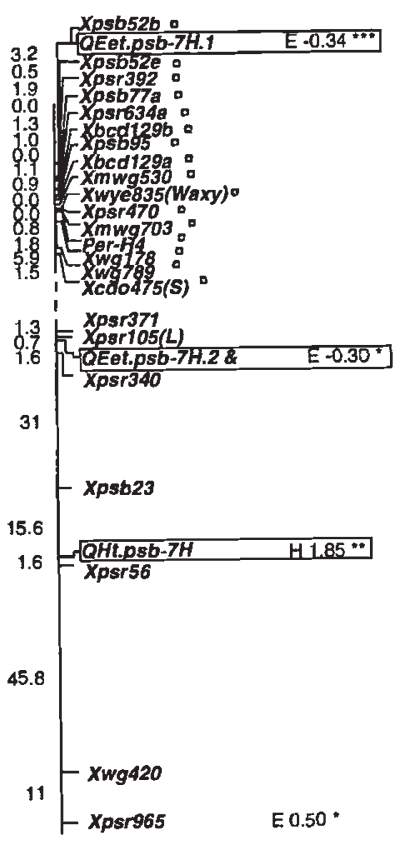

(C) The Genetical Society of Great Britain, Heredity, 77, 64-73. 
an additive effect of $6.76 \mathrm{~cm}$ (see Fig. 1). The decreasing alleles came from Blenheim as expected.

Two other QTL were detected, one on $7(5 \mathrm{H}) \mathrm{L}$ and one on $1(7 \mathrm{H}) \mathrm{L}$. The shorter-plant allele of the $7(5 \mathrm{H}) \mathrm{L}$ QTL came from the Blenheim parent with an additive effect of $1.46 \mathrm{~cm}$. The shorter-plant allele of the $1(7 \mathrm{H}) \mathrm{L}$ QTL came from Kym with an additive effect of $1.85 \mathrm{~cm}$ and was the only heightreducing effect detected from the Kym parent. Summing the additive effects of the QTL identified we would expect to see $\approx 10.06 \mathrm{~cm}$ difference between the shortest or tallest line and the mean. This gives an expected range of $20.11 \mathrm{~cm}$; however, the observed range was $37 \mathrm{~cm}$. The lack of other height-reducing QTL, particularly from Kym, suggests that there may be additional effects in regions not covered by the map or that a number of genes of small effect were involved that were not detected.

\section{$Q T L$ for ear emergence time}

Blenheim consistently flowered 1.8 days later than Kym in this study. Eight loci controlling ear emergence time (EET) were detected using the MR approach. The largest effect was a delay in EET attributable to the denso dwarfing gene, where there was an additive effect of 2.05 days. The denso locus accounts for 61 per cent of the variation in EET. Early flowering alleles of QTL detected at the denso locus and on chromosome arms $5(1 \mathrm{H}) \mathrm{S}(0.32$ days $)$ and $4(4 \mathrm{H}) \mathrm{L}$ (1 day) came from Kym whereas those of QTL detected on chromosome arms $2(2 \mathrm{H}) \mathrm{S}(0.52$ days $), 7(5 \mathrm{H}) \mathrm{L}(0.42$ days $), 6(6 \mathrm{H}) \mathrm{L}(0.61$ days $)$, $1(7 \mathrm{H}) \mathrm{S}(0.34$ days $)$ and $1(7 \mathrm{H}) \mathrm{L}(0.3$ days $)$ came from Blenheim. Three further significant EET effects were detected by ANOVA and were associated with the markers $\mathrm{Xps} 901$ on chromosome $2(2 \mathrm{H}), \quad X m w g 652$ on chromosome $6(6 \mathrm{H}) \mathrm{S}$ and Xpsr965 on chromosome 1(7H)L. Early flowering alleles on $6(6 \mathrm{H}) \mathrm{S}(0.67$ days $)$ and $1(7 \mathrm{H}) \mathrm{L}(0.5$ days $)$ came from Kym and the early allele on $2(2 \mathrm{H})(0.51$ days) from Blenheim.

Assuming that all EET effects are purely additive the difference between the parent allele groups is 1.84 days. This is approximately equal to the 1.8 days difference between the parental means. The loci detected accounted for most of the observed variation in EET so it is likely that there are no additional major effects. The observed range between the earliest and latest lines was 9.5 days and the expected range was 12.48 days. This suggests that nonadditive interactions may be involved that reduce the allelic effects of the QTL.

\section{Marker-regression QTL profiles}

The effect of the denso dwarfing gene on plant height and ear emergence time can be seen in Fig. 2. For EET the expected plot closely follows the observed $\delta_{i}$ for each marker. This observation fits the single QTL per linkage group model. However, for height the maximum for the expected QTL is lower than the observed. This may result from small proximal positive effects causing the observed values to fall away more sharply than expected after the QTL maximum. Similarly on chromosome $7(5 \mathrm{H})$ the expected values are very different from the observed for most markers on the chromosome for both traits. By examining the observed $\delta_{i}$ we can see that the other loci exhibit nonsignificant but visible associations with both traits in repulsion to the detected QTL. Thus, the QTL maxima may be underestimated.

MAPMAKER/QTL (MM) (Lander \& Botstein, 1989) was also used to scan the chromosomes for QTL (see Fig. 2). MM was observed to be less sensitive when compared to MR and ANOvA. For example, using the default LOD score of 2, no significant QTL were detected for ear emergence time or height on the long arm of chromosome $7(5 \mathrm{H})$. LOD scores peaked at 0.86 and 1.54 for intervals in which MR placed QTL for ear emergence time and height.

\section{Comparative mapping of $Q T L$}

Comparative mapping of wheat (Triticum aestivum), rye (Secale cereale) and barley using RFLP markers shows that when translocations are taken into account the order of loci on equivalent (homoeologous) chromosome segments is conserved (Devos et al., 1993a,b). This predicts that genes controlling plant performance should appear in equivalent locations both within and between species. Thus, genes can be considered as having a homoeoallelic series that spans several crop species. For a given gene, some allele combinations may appear as major gene differences whereas others (in other crosses or other species) appear as QTL (Robertson, 1985). It is therefore of interest to consider what proportion of QTL in the Blenheim $\times$ Kym cross falls into regions previously identified as having major genes controlling plant height or flowering time.

Takahashi \& Yasuda (1971) identified three genes controlling vernalization response, $S h, S h 2$ and $S h 3$, which are now known to lie on barley chromosomes $4(4 \mathrm{H}), 7(5 \mathrm{H})$ and $5(1 \mathrm{H})$. Recently Laurie et al. (1995) mapped the spring habit genes $S h$ and $S h 2$ in a cross between a winter and spring barley. Sh2 


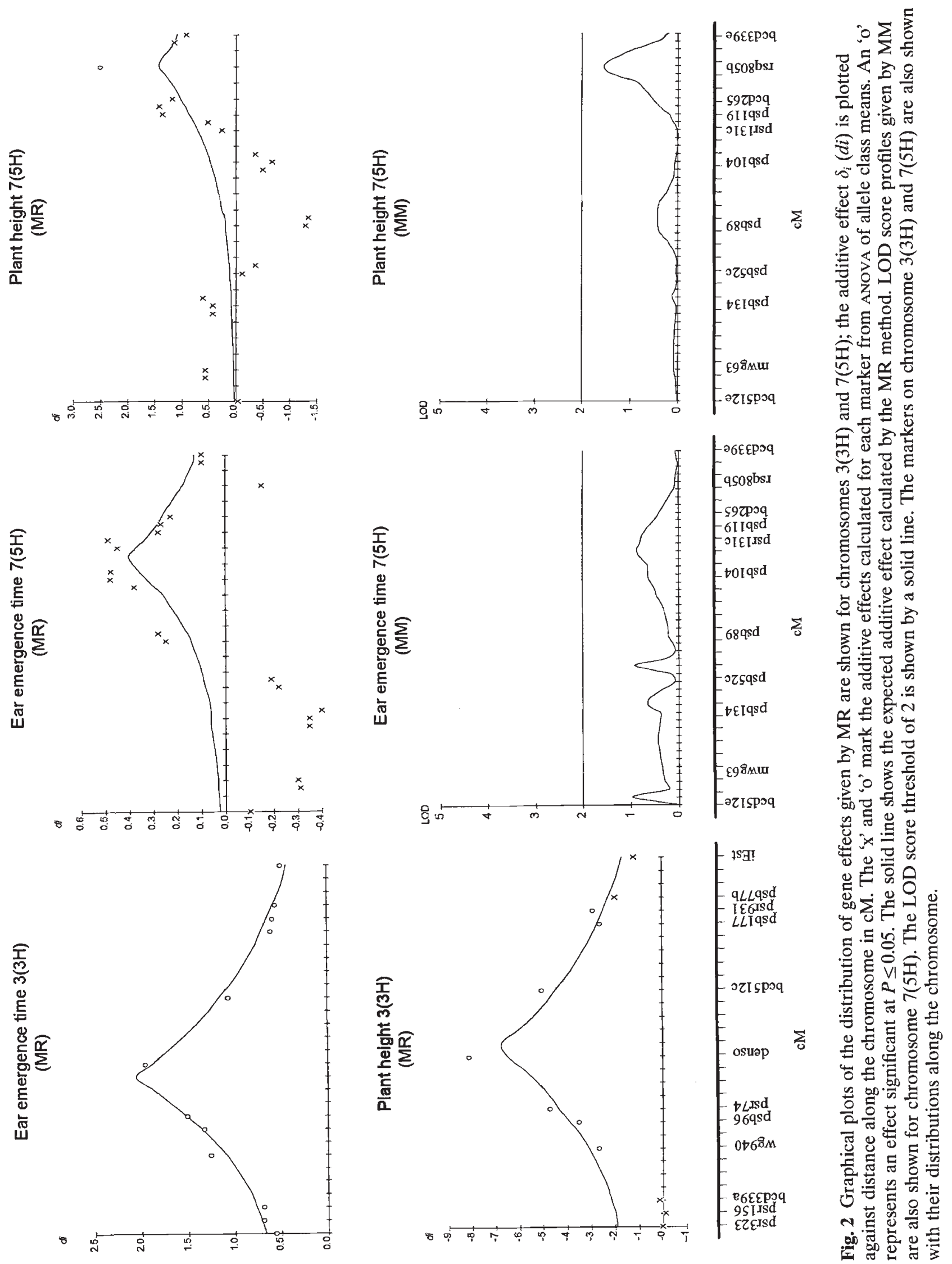


maps to the same region of the homoeologous group 5 chromosomes as the vernalization response genes Vrn1 in wheat (Galiba et al., 1995) and Sp1 in rye (Plaschke et al., 1993) suggesting that these genes are part of a homoeoallelic series.

Two of the QTL mapped in the Blenheim $\times$ Kym cross lie in the same regions as $S h$ and $S h 2$ on chromosomes $4(4 \mathrm{H}) \mathrm{L}$ and $7(5 \mathrm{H}) \mathrm{L}$ (see Figs 3 and 4). Hayes et al. (1993b) identified a locus controlling ear emergence time close to $\beta-A m y-H 1$. Allelic variation for the $S h$ and $S h 2$ genes in spring barley would be consistent with previous reports showing a multiple allelic series at the $S h 2$ locus that accounted for gradations in winter-growth habit (Takahashi \& Yasuda, 1971). Pan et al. (1994) concluded that their accession of the winter barley Dicktoo carried a vernalization responsive allele at a locus corresponding to the $S h 2$ gene although it does not have a vernalization requirement. A simple explanation would be that within spring barleys there are subgroups of alleles, with different degrees of vernalization sensitivity, controlling ear emergence time and giving rise to some of the genetic variation between varieties and the differences we have seen here.
Laurie et al. (1995) also detected a number of 'earliness per se genes' which affect flowering time largely independently of environmental cues. A QTL detected on chromosome $6(6 \mathrm{H}) \mathrm{L}$ in Blenheim $\times$ Kym (QEet.psb-6H) lies in the same interval (Xmwg820-X $\alpha-A m y 1$ ) as the gene eps6L in that cross.

Several early flowering recessive mutants have been described including $e a_{s p}, e a_{c}, e a^{k}$ and $e a 7$ on chromosomes $3(3 \mathrm{H}), 4(4 \mathrm{H}), 5(1 \mathrm{H})$ and $6(6 \mathrm{H})$, respectively (Takahashi \& Yasuda, 1971; Sogaard \& von Wettstein-Knowles, 1987; Gallagher et al., 1991; von Wettstein-Knowles, 1992). In spring barley some of the variation in ear emergence time is thought to be controlled by these $e a$ maturity loci (Gallagher $e t$ al., 1991); however, no QTL were detected in the same locations (where known) as these ea maturity loci.

Hayes et al. (1993b) also detected a QTL affecting flowering time on chromosome $2(2 \mathrm{H}) \mathrm{S}$. Laurie et al. (1995) mapped the photoperiod sensitivity locus, Ppd-H1, on $2(2 \mathrm{H}) \mathrm{S}$ distal to Xpsb9. In this study a QTL was detected proximal to Xpsb9 but it is not clear whether this might be an effect of variation at Ppd-H1.

Many dwarfing genes have been identified in a

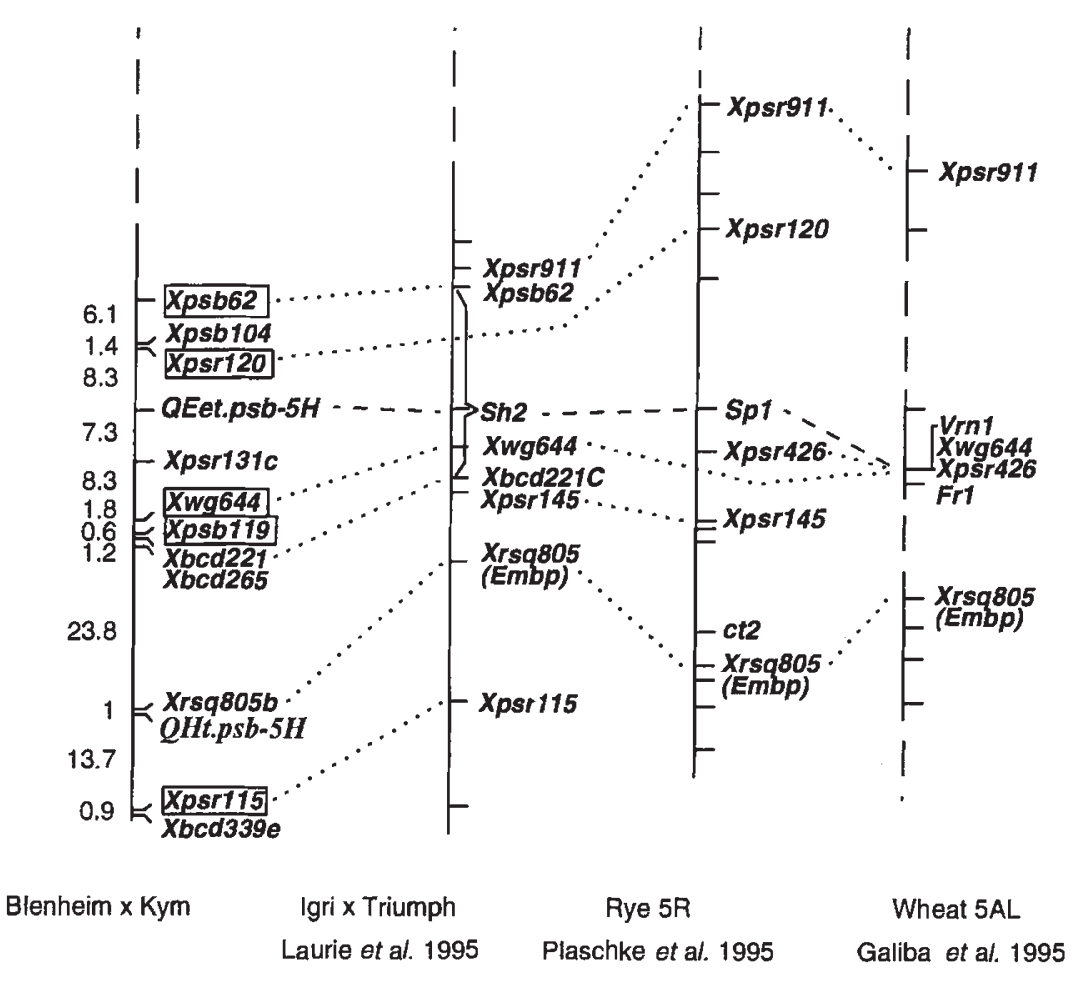

Chromosome $7(5 \mathrm{H}) \mathrm{L}$
Fig. 3 Comparative RFLP maps of the long arms of the group 5 chromosomes of wheat, barley and rye showing the possible homoeoallelic relationship between $S p l$ on rye 5RL, $V m I$ on wheat $5 \mathrm{AL}$ and $S h 2$ on barley $7(5 \mathrm{H}) \mathrm{L}$. Common marker loci are indicated by a dotted line. Single-copy markers in the Blenheim $\times$ Kym cross are in boxes. 
Fig. 4 Comparative RFLP maps of the long arm of chromosome $4(4 \mathrm{H}) \mathrm{L}$ of several barley crosses for the $S h$ region. The locus $V 1$ mapped by Hackett et al. (1992) is analogous to Sh. Common marker loci are indicated by a dotted line. Single-copy markers in the Blenheim $\times$ Kym cross are in boxes.

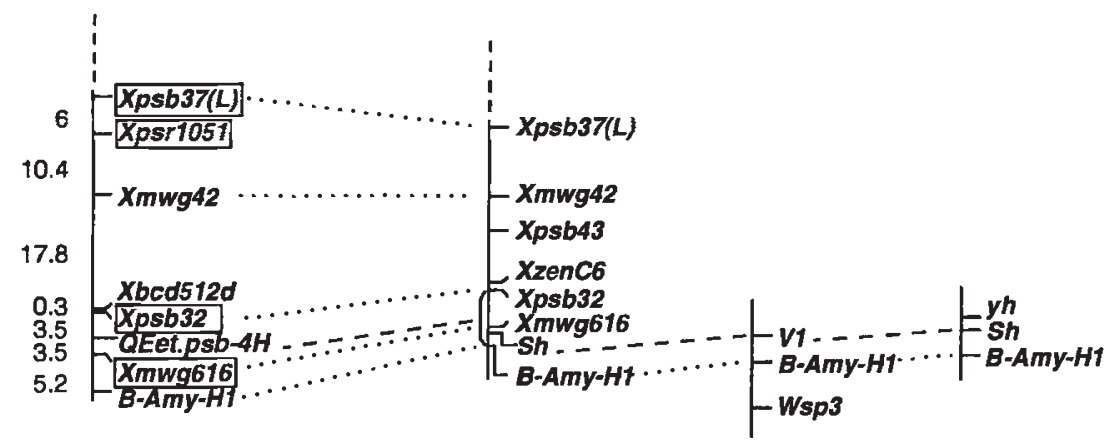

Blenheim $x$ Kym
Chojecki et al. 1989
Igri $\times$ Triumph
Laurie et al. 1995
Gerbel $x$ Heriot Hackett et al. 1992

\section{Chromosome 4(4H)L}

wide range of species but relatively few have been mapped in relation to RFLP markers. The denso dwarfing gene is a major gene that is carried by many barley varieties currently in use. No equivalent gene has yet been identified in other species. Interestingly, however, the height QTL located on chromosomes $7(5 \mathrm{H}) \mathrm{L}$ (see Fig. 3) and $1(7 \mathrm{H}) \mathrm{L}$ map to the same regions as the $c t 2$ (Plaschke et al., 1993) and ct1 (Plaschke et al., 1995) dwarfing genes in rye, respectively.

\section{Discussion}

As expected the denso gene from the Blenheim parent had a major effect on final plant height and ear emergence time in this cross. This gene accounted for 61 per cent of the variation in ear emergence time and 67 per cent of the variation in height. However, the MR method was able to detect and locate several other genes controlling these characters.

An advantage of the MR method is that it utilizes information from all the markers in the linkage group in a single test. This enables the detection of QTL that lie between flanking markers that individually may show no significant association with the trait. Where two or more QTL are present in the same linkage group marker-regression locates the largest QTL and indicates the existence of the others using the residual mean square. By examining the additive effects at each marker locus the location of subsequent QTL can be estimated. ANOVA of allele class means is useful for analysing unlinked markers.

For a complete analysis, a comprehensive molecular marker map is required which covers the whole genome. Using RFLP markers this can be a difficult and time consuming task. Recent developments in PCR-based marker technology such as AFLP (Amplified Fragment Length Polymorphism) (Vos et al., 1995) enable large numbers of markers to be generated in a short time. However, because time can also be saved by making comparisons between crosses and between species where homoeologous relationships are known, it would be desirable to include common marker sets of single-copy probes to allow map alignment, comparative mapping and QTL-major gene comparison. RFLP markers, particularly cDNA clones, are ideal for this purpose because they are often found to be transferable between species (Ahn \& Tanksley, 1993; Devos et al., 1993b; Kurata et al., 1994).

It is important to determine to what extent QTL in one cross may be equivalent to major genes in others, because this would allow close flanking markers for the major genes to be used to manipulate QTL in other crosses and other species. This would greatly increase the efficiency of marker-assisted selection of QTL and the accuracy with which specific combinations of QTL could be put together.

\section{Acknowledgements}

We thank Dr Andreas Graner (Institut für Resistenzgenetik, Grünbach, Germany) and Dr Mark Sorrells (Cornell University, Ithaca, USA) for probes. JHB is the recipient of a SERC-CASE studentship with the University of Birmingham and Zeneca Seeds U.K. Ltd.

\section{References}

AHN, S. AND TANKsley, S. D. 1993. Comparative linkage maps of the rice and maize genomes. Proc. Natl. Acad. 
Sci. U.S.A., 90, 7980-7984.

ASINS, M. J., MESTRE, P., GARCIA, J. E., DICENTA, F. AND CARBONEll, E. A. 1994. Genotype-environment interaction in QTL analysis of an intervarietal almond cross by means of genetic markers. Theor. Appl. Genet., 89, 358-364.

BACKES, G., GRANER, A., FOROUGHI-WEHR, B., FISCHBECK, G., WENZEL, G. AND JAHOOR, A. 1995. Localisation of quantitative trait loci (QTL) for agronomic important characters by the use of a RFLP map in barley (Hordeum vulgare L.). Theor. Appl. Genet., 90, 294-302.

BARUA, U. M., CHALMERS, K. J., THOMAS, W. T. B., HACKETT, C. A., LEA, V., JACK, P., FORSTER, B. P., WAUGH, R. AND POWELL, W. 1993. Molecular mapping of genes determining height, time to heading, and growth habit in barley (Hordeum vulgare). Genome, 36, 1080-1087.

CHOJECKI, J., BARNES, S. AND DUNLOP, A. 1989. A molecular marker for vernalization requirement in barley. In: Helentjaris, T. and Burr, B. (eds) Development and Application of Molecular Markers to Problems in Plant Genetics, pp. 145-148. Cold Spring Harbor Laboratory, Cold Spring Harbor, NY.

DEVOS, K. M., ATKINSON, M. D., CHINOY, C. N., LIU, C. J. AND GALE, M. D. 1992. RFLP-based genetic map of the homoeologous group 3 chromosomes of wheat and rye. Theor. Appl. Genet., 83, 931-939.

DEVOS, K. M., ATKINSON, M. D., CHINOY, C. N., FRANCIS, H. A., HARCOURT, R. L., KOEBNER, R. M. D., LIU, C. J., MASOJC, P., XIE, D. X. AND GALE, M. D. 1993a. Chromosomal rearrangements in the rye genome relative to that of wheat. Theor. Appl. Genet., 85, 673-680.

Devos, K. M., Millan, T. AND GAle, M. D. 1993b. Comparative RFLP maps of the homoeologous group 2 chromosomes of wheat, rye and barley. Theor. Appl. Genet., 85, 784-792.

EDWARDS, M. D., HELENTJARIS, T., WRIGHT, S. AND STUbER, C. W. 1992. Molecular marker facilitated investigations of quantitative trait loci in maize. 4. Analysis based on genome saturation with isozyme and restriction-fragment-length-polymorphism markers. Theor. Appl. Genet., 83, 765-774.

GALIBA, G., QUARRIE, S. A., SUTKA, J., MORGOUNOV, A. AND SNAPE, J. W. 1995. RFLP mapping of the vernalization $(V r n l)$ and frost resistance $(F r l)$ genes on chromosome 5 A of wheat. Theor: Appl. Genet., 90, 1174-1179.

GALlAGHER, L. W., SOLIMAN, K. M. AND VIVAR, H. 1991. Interactions among loci conferring photoperiod insensitivity for heading time in spring barley. Crop Sci., 31, 256-261.

Genstat 5 COMmittee. 1987. Genstat 5 reference manual. Clarendon Press, Oxford.

GRANER, A., JAHOOR, A., SCHONDElMAIER, J., SIEDLER, H., PILLEN, K., FISCHBECK, G., WENZEL, G. AND HERRMANN, R. G. 1991. Construction of an RFLP map of barley. Theor. Appl. Genet., 83, 250-256.

GUILTINAN, M. J., MARCOTTE, w. R., Jr and quatrano, r. s. 1990. A plant leucine zipper protein that recognizes an abscisic acid response element. Science, 250, 267-271.

HACKETT, C. A., ELlis, R. P., FORSTER, B. P., MCNICOL, J. W.
AND MACAulay, m. 1992. Statistical analysis of a linkage experiment in barley involving quantitative trait loci for height and ear-emergence time and two genetic markers on chromosome 4. Theor. Appl. Genet., 85, 120-126.

HALEY, C. S. AND KNOTT, S. A. 1992. A simple regression method for mapping quantitative trait loci in line crosses using flanking markers. Heredity, 69, 315-324.

HAYES, P. M., BLAKE, T., CHEN, T. H. H., TRAGOONRUNG, S., CHEN, F., PAN, A. AND LIU, B. 1993a. Quantitative trait loci on barley (Hordeum vulgare L.) chromosome 7 associated with components of winterhardiness. Genome, 36, 66-71.

HAYES, P. M., LIU, B. H., KNAPP, S. J., CHEN, F., JONES, B., BLAKE, T., FRANCKOW1AK, J. D., RASMUSSON, D., SORRELLS, M. E., ULLRICH, S. E., WESENBERG, D. AND KLEINHOFS, A. 1993b. Quantitative trait locus effects and environmental interaction in a sample of North American barley germ plasm. Theor. Appl. Genet., 87, 392-401.

HEUN, M., KENNEDY, A. E., ANDERSON, J. A., LAPITAN, N. L. V., SORRELLS, M. E. AND TANKSLEY, S. D. 1991. Construction of a restriction fragment length polymorphism map for barley (Hordeum vulgare). Genome, 34, 437-447.

ISLAM, A. K. M. R. 1983. Ditelosomic additions of barley chromosomes to wheat. In: Sakamoto, S. (ed.) Proceedings of the 6th International Wheat Genetics Symposium, pp. 233-238. Maruzen Co. Ltd, Kyoto.

JANSEN, R. C. 1992. A general mixture model for mapping quantitative trait loci by using molecular markers. Theor. Appl. Genet., 85, 252-260.

KEARSEY, M.J. AND HYNE, V. 1994. QTL analysis: a simple 'marker regression' approach. Theor. Appl. Genet., 89, 698-702.

KURATA, N., MOORE, G., NAGAMURA, Y., FOOTE, T., YANO, M., MINOBE, Y. AND GALE, M. D. 1994. Conservation of genome structure between rice and wheat. Bio/Technology, 12, 276-278.

LANDER, E. S. AND BOTSTEIN, D. 1989. Mapping Mendelian factors underlying quantitative traits using RFLP linkage maps. Genetics, 121, 185-199.

LAURIE, D. A., PRATCHETT, N., ROMERO, C., SIMPSON, E. AND SNAPE, J. W. 1993. Assignment of the denso dwarfing gene to the long arm of chromosome $3(3 \mathrm{H})$ of barley by use of RFLP markers. Pl. Breed., 111, 198-203.

LAURIE, D. A., PRATCHETT, N., BEZANT, J. H. AND SNAPE, J. w. 1995. RFLP mapping of five major genes and eight QTL controlling flowering time in a winter $\times$ spring (Hordeum vulgare L.) cross. Genome, 38, 575-585.

LAZARUS, C. M., BAULCOMBE, D. C. AND MARTIENSSEN, R. A. 1985. $\alpha$-amylase genes of wheat are two multigene families which are differentially expressed. Plant Mol. Biol., 5, 13-24.

LIU, C. J., CHAO, S. AND GALE, M. D. 1990. The genetical control of tissue-specific peroxidases, Per-1, Per-2, Per-3, Per-4, and Per-5 in wheat. Theor. Appl. Genet., 79, 305-313.

MARTINEZ, O. AND CURNOW, R. N. 1992. Estimating the locations and the sizes of the effects of quantitative 
trait loci using flanking markers. Theor. Appl. Genet., 85, 480-488.

MURRAY, M. G. AND THOMPSON, W. F. 1980. The isolation of high molecular weight plant DNA. Nucl. Acids Res., 8, 4321-4325.

N.I.A.B. 1994. NIAB Recommended Lists of Cereals. Cereal Variety Handbook. National Institute of Agricultural Botany, Cambridge.

PAN, A., HAYES, P. M., CHEN, F., CHEN, T. H. H., BLAKE, T., WRIGHT, S., KARSAI, I. AND BEDO, z. 1994. Genetic analysis of the components of winterhardiness in barley (Hordeum vulgare L.). Theor. Appl. Genet., 89, 900-910.

PAYNE, P. I., CORFIELD, K. G., HOLT, L. M. AND BLACKMAN, J. A. 1981. Correlations between the inheritance of certain high-molecular weight subunits of glutenin and bread-making quality in progenies of six crosses of bread wheat. J. Sci. Food Agric., 32, 51-60.

PLASCHKE, J., BÖRNER, A., XIE, D. X., KOEBNER, R. M. D., SCHLEGEL, R. AND GALE, M. D. 1993. RFLP mapping of genes affecting plant height and growth habit in rye. Theor. Appl. Genet., 85, 1049-1054.

PLASCHKE, J., KORZUN, V., KOEBNER, R. M. D. AND BÖRNER, A. 1995. Mapping the GA3-insensitive dwarfing gene ctl on chromosome 7 in rye. Pl. Breed., 114, 113-116.

ROBERTSON, D. S. 1985. A possible technique for isolating genic DNA for quantitative traits in plants. $J$. Theor. Biol., 117, 1-10.

ROHDE, W., BECKER, D. AND SALAMINI, F. 1988. Structural analysis of the waxy locus from Hordeum vulgare. Nucl. Acids Res., 16, 7185-7186.

SHARP, P. J., DESAI, S. AND GALE, M. D. 1988. Isozyme variation and RFLPs at the $\beta$-amylase loci in wheat. Theor. Appl. Genet., 76, 691-699.
SIMPSON, E. AND SNAPE, J. w. 1981. The use of doubled haploids in a winter barley programme. In: Asher, M. J. C., Ellis, R. P., Hayter, A. M. and Whitehouse, R. N. H. (eds) Barley Genetics IV: Proceedings of the 4th International Barley Genetics Symposium, pp. 716-720. Edinburgh University Press, Edinburgh.

SOGAARD, B. AND VON WETTSTEIN-KNOWLES, P. 1987. Barley: genes and chromosomes. Carlsberg Res. Comm., 52, 123-196.

STAM, P. 1993. Construction of integrated genetic linkage maps by means of a new computer package: JoinMap. Plant J., 3, 739-744.

TABATA, M. 1961. Studies of a gametophyte factor in barley. Jap. J. Genet., 36, 157-167.

TAKAHASHI, R. AND YASUDA, s. 1971. Genetics of earliness and growth habit in barley. In: Nilan, R.A. (ed.) Barley Genetics II: Proceedings of the 2nd International Barley Genetics Symposium, pp. 388-408. Washington State University Press, Pullman, WA.

VON WETTSTEIN-KNOWLES, P. 1992. Cloned and mapped genes: current status. In: Shewry, P.R. (ed.) Barley: Genetics, Biochemistry, Molecular Biology and Biotechnology, pp. 73-98. C.A.B. International, Wallingford, U.K.

VOS, P., HOGERS, R., BLEEKER, M., REIJANS, M., VANDELEE, T., HORNES, M. ET AL. 1995. AFLP - a new technique for DNA-fingerprinting. Nucl. Acids Res., 23, 4407-4414.

WORLAND, A. J. 1995. The influence of flowering time genes on environmental adaptability in European wheats. Euphytica, 89, 49-57.

ZENG, Z.-B. 1994. Precision mapping of quantitative trait loci. Genetics, 136, 1457-1468. 